\title{
Kajian Pengembangan Jaringan Distribusi Air Bersih pada PDAM Tirta Barito Kota Buntok
}

\author{
A Study on the Development of Clean Water Distribution Network at PDAM \\ Tirta Barito, Buntok City
}

\author{
Eka Wahyu Diana ${ }^{1 *}$, Mohammad Sholichin ${ }^{2}$, Riyanto Haribowo ${ }^{2}$ \\ ${ }^{1}$ Dinas Pekerjaan Umum dan Penataan Ruang, Kabupaten Barito Selatan, Indonesia \\ ${ }^{2}$ Jurusan Teknik Pengairan, Fakultas Teknik, Universitas Brawijaya, Malang, Indonesia
}

Article info:

Kata kunci:

air bersih, harga air, jaringan perpipaan, sisa klorin

Keywords:

clean water, pipe network, residual chlorine, water prices

Article history:

Received: 01-08-2019

Accepted: 14-02-2020

*)Koresponden email:

ek_wd@yahoo.com
PDAM Kota Buntok merupakan penyuplai kebutuhan air bersih wilayah Buntok Kota, Hilir Sper, Jelapat dan Desa Pamait. Pemanfaatan debit belum optimal dan kehilangan air menjadi kendala pelayanan. Penelitian ini bertujuan mewujudkan sistem jaringan distribusi yang mampu melayani hingga 2038 dengan mengevaluasi kondisi eksisting jaringan distribusi air bersih, rencana pengembangan jaringan, kualitas air dan analisa ekonomi untuk menentukan harga air. Hasil simulasi hidrolika menunjukkan kondisi eksisting tekanan dan headloss gradient memenuhi kriteria teknis sedangkan kecepatan tidak sesuai standar. Kemudian simulasi pengembangan memenuhi persyaratan teknis yaitu 0.3-4.5 $\mathrm{m} / \mathrm{dt}$, headloss gradient $0-15 \mathrm{~m} / \mathrm{km}$, tekanan $0.5-8$ atm. Simulasi konsentrasi sisa klorin injeksi di inlet tandon sebesar $0.4 \mathrm{mg} / \mathrm{l}$ diberikan secara konstan. Hasil simulasi sisa klorin memenuhi kriteria yaitu $0.383-0.395 \mathrm{mg} / \mathrm{l}$. Analisis ekonomi didapatkan harga

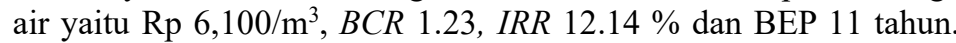

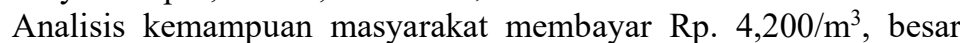
subsidi pemerintah sebesar Rp. 13,905,747,800.

Abstract
PDAM of Buntok City is a supplier of clean water needs for the
area of Buntok Kota, Hilir Sper, Jelapat and Pamait villages.
Utilization of discharge is not optimal and water loss is service
constraint. This study aims to realize a distribution network system
that is able to serve up to 2038 by evaluating the existing
conditions of clean water distribution networks, network
development plans, water quality and economic analysis to
determine water prices. The results of hydraulic simulation show
that the existing conditions of pressure and headloss gradient meet
technical criteria while the speed is not up standard. Then the
development simulation meets the technical requirements of $0.3-$
4.5 m/s, headloss gradient $0-15$ m/km, pressure $0.5-8$ atm.
Simulation of residual injection chlorine concentration at the inlet
reservoir of 0.4 mg/l are given constantly. The results of residual
chlorine simulation meet the criteria of $0.383-0.395$ mg/l.
Economic analysis found that water prices were Rp. $6,100 / \mathrm{m}^{3}$,
BCR 1.23 , IRR $12.14 \%$ and $11-y e a r$ BEP. Analysis of the ability of
the community to pay Rp. $4,200 / \mathrm{m}^{3}$, the amount of government
subsidy is Rp. $13,905,747,800$.




\section{Pendahuluan}

Air merupakan kebutuhan penting yang mempengaruhi banyak aspek kehidupan manusia. Air mendukung kehidupan manusia, jika dikelola dengan baik. Pertumbuhan populasi, perubahan gaya hidup, penurunan layanan ekosistem dan perubahan iklim dapat mengurangi akses ke kualitas dan kuantitas air yang memadai serta meningkatkan variabilitas dan besarnya kejadian ekstrim. Kurangnya akses ke air tawar dan risiko yang semakin meningkat dalam kejadian ekstrim akan lebih sulit untuk mencapai keberlanjutan sumber daya air (Siska and Takara 2015). Faktor perubahan iklim dan akses distribusi berpengaruh dalam keberlangsungan pemenuhan kebutuhan air bersih meskipun ketersediaan air cukup besar dan hal ini berdampak bagi organisasi air yang bertugas dalam pengelolaan kebutuhan sosial dan ekologi untuk air (Azhoni, Jude, and Holman 2018) and (Susilo and Jafri 2019).

Rencana pengembangan jaringan distribusi air diperlukan pengumpulan informasi karakteristik fisik suatu sistem dan menetapkan tingkat konsumsi adalah proses yang membutuhkan studi tentang tren penggunaan masa lalu, sekarang dan proyeksi yang akan datang. Setelah tingkat konsumsi ditentukan, penggunaan air didistribusikan secara spasial sebagai beban kebutuhan untuk memodelkan simpul. Proses ini disebut sebagai membuat model. Model dapat digunakan untuk memecahkan masalah yang sedang berlangsung, menganalisis operasional yang diusulkan perubahan dan bersiap untuk kejadian yang tidak biasa. Dengan membandingkan hasil model dengan operasi lapangan, operator dapat menentukan penyebab masalah dalam sistem dan merumuskan solusi yang akan berfungsi dengan benar pada kali pertama, alih-alih beralih ke cobacoba perubahan dalam sistem yang sebenarnya (M. Walski et al. 2003).

Model jaringan memainkan peran penting dalam desain, operasi dan manajemen sistem distribusi air (Izinyon and Anyata 2009). Penelitian ini simulasi menggunakan program WaterCad $V 8 i$ untuk menganalisa kondisi hidrolik pada jaringan distribusi air dengan perhitungan arus dan tekanan dalam jaringan pipa yang dimodelkan secara relatif. WaterCADV8i merupakan perangkat lunak pemodelan hidraulik yang terdiri dari berbagai fungsi termasuk kemajuan grafis dan profil, fleksibel (Sonaje and Joshi 2015). Banyak fitur seperti hidrolik dan air analisis kualitas, steady state dan simulasi jangka panjang juga dibuat berfungsi dengan kemampuan yang ditingkatkan, kuat manajemen data bersama dengan integrasi AutoCAD dan GIS. Keunggulan WaterCAD V8i dibanding software lainnya termasuk pembuatan model yang disederhanakan dengan modul geospasial dan alat seperti Load Builder dan TRex, pemodelan kualitas air, analisis aliran, optimasi dan manajemen skenario. WaterCAD V8i dengan mudah digunakan untuk berbagai jenis distribusi air serta paket perangkat lunak pemodelan kualitas diterima untuk berbagai aplikasi (Sonaje and Joshi 2015).

Tujuan dari penelitian ini untuk mewujudkan peningkatan sistem pengembangan jaringan air bersih yang mampu melayani hingga tahun 2038 dengan mengevaluasi kondisi jaringan eksisting, rencana pengembangan jaringan, kualitas air yang ditinjau dengan simulasi injeksi klorin serta analisa ekonomi untuk mengetahui harga air dan selanjutnya dapat menjadi masukan bagi PDAM Tirta Barito guna meningkatkan jaringan distribusi air bersih dan mendukung pemenuhan air bersih yang merata dan tersalur dengan baik di Kota Buntok.

\section{Material dan Metode}

Kajian ini diawali dengan mengevaluasi kondisi eksisting jaringan distribusi air bersih dan rencana pengembangan jaringan dengan kebutuhan air hingga tahun 2038 dan aspek kualitas air akan mensimulasikan injeksi klorin untuk mematikan bakteri pathogen untuk menjaga kualitas air agar layak konsumsi serta analisa ekonomi untuk mengetahui harga air yang ditinjau dari NPV, $\mathrm{BCR}, \mathrm{BEP}$ dan IRR.

\subsection{Wilayah Studi}

Wilayah studi ditunjukan pada Gambar 1 dengan wilayah pelayanan PDAM Kota Buntok untuk Zona Layanan BNA Buntok meliputi 3 Kelurahan dan 1 Desa yaitu Buntok Kota, Hilir Sper, Jelapat dan Pamait dengan luas daerah layanan $215 \mathrm{~km}^{2}$. Kapasitas produksi sebesar $85 \mathrm{lt} / \mathrm{dt}$ dan secara astronomis terletak pada $1^{\circ} 20^{\prime} \mathrm{LU}-2^{\circ} 35^{\prime} \mathrm{LS}$ dan $114^{\circ}-115^{\circ} \mathrm{BT}$. Topografi wilayah Kabupaten Barito Selatan merupakan daerah dataran rendah dengan relatif landai. Sumber air 
didapatkan dari Sungai Barito. Sistem pengaliran menggunakan pompa. Kapasitas instalasi pengolahan air bersih sebesar $85 \mathrm{lt} / \mathrm{dt}$, kapasitas reservoir 1,000 $\mathrm{m}^{3}$. Pada Tabel 1 menyajikan corak variasi kebutuhan air bersih harian pada junction yang dihitung dengan menggunakan metode pendekatan corak fluktuasi kebutuhan air bersih harian yang telah dilakukan oleh (Direktorat Jenderal Cipta Karya 2007) Departemen PU karena metode ini berdasarkan penelitian ragam kebutuhan air bersih sepanjang waktu di Indonesia yang diasumsikan dapat mewakili fluktuasi kebutuhan air bersih.

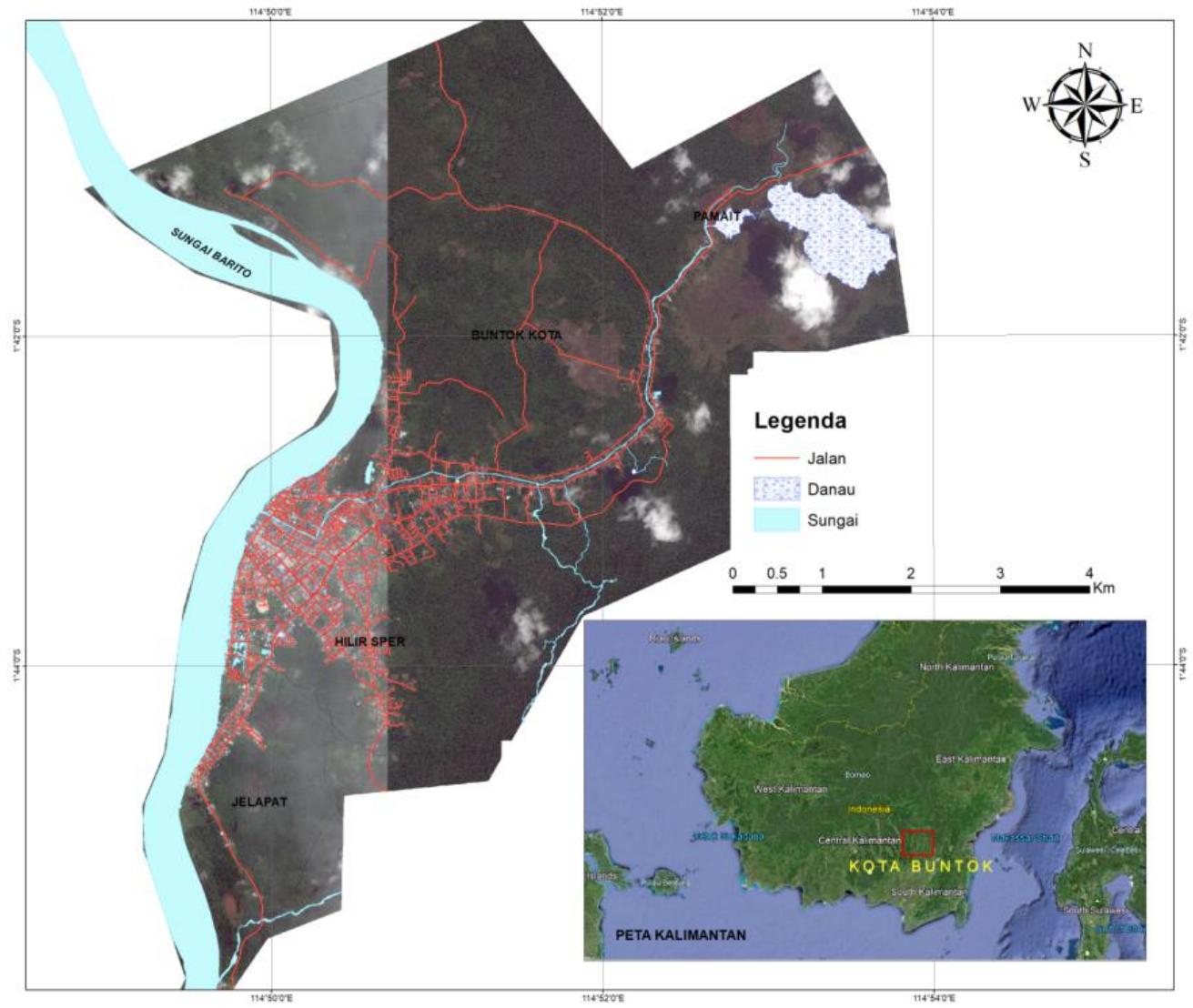

Gambar 1. Lokasi Studi

Tabel 1. Load factor (LF) terhadap kebutuhan harian

\begin{tabular}{|c|c|c|c|c|c|}
\hline Jam & LF & Jam & LF & Jam & LF \\
\hline 1 & 0.31 & 9 & 1.42 & 17 & 1.31 \\
\hline 2 & 0.37 & 10 & 1.38 & 18 & 1.38 \\
\hline 3 & 0.45 & 11 & 1.27 & 19 & 1.25 \\
\hline 4 & 0.64 & 12 & 1.2 & 20 & 0.98 \\
\hline 5 & 1.15 & 13 & 1.14 & 21 & 0.62 \\
\hline 6 & 1.4 & 14 & 1.17 & 22 & 0.45 \\
\hline 7 & 1.53 & 15 & 1.18 & 23 & 0.37 \\
\hline 8 & 1.56 & 16 & 1.22 & 24 & 0.25 \\
\hline
\end{tabular}

Tabel 2. Kriteria Pipa

\begin{tabular}{|c|c|}
\hline Keterangan & Pipa PVC \\
\hline Kecepatan & $0.3-4.5 \mathrm{~m} / \mathrm{dt}$ \\
\hline Headloss Gradient & $0-15 \mathrm{~m} / \mathrm{km}$ \\
\hline Tekanan & $0.5-8 \mathrm{~atm}$ \\
\hline
\end{tabular}




\subsection{Pengumpulan Data}

Data-data yang digunakan pada kajian ini adalah

1. Data jumlah penduduk tahun 2009-2018 Kabupaten Barito Selatan

2. Peta jaringan pipa eksisting PDAM Tirta Barito Kota Buntok dan data topografi

3. Data jumlah Sambungan Rumah (SR)

4. Data kualitas air hasil produksi

5. Daftar harga satuan upah dan bahan Kabupaten Barito Selatan 2018.

6. Data kemampuan membayar warga melalui pembagian kuisioner.

\subsection{Pengolahan Data}

1. Memprediksi jumlah penduduk. Prediksi dihitung dengan metode Geometrik, metode Aritmatik dan metode Eksponensial (Lufira and Marsudi 2012). Rencana induk SPAM disusun untuk jangka waktu 15-20 tahun (Kementerian Pekerjaan Umum 2016). Pada kajian ini, prediksi penduduk dilakukan selama 20 tahun, tahun analisa dimulai 2019 hingga 2038.

2. Membandingkan nilai koefisien korelasi untuk menguji kesesuaian metode prediksi penduduk.

3. Perhitungan besar kebutuhan air bersih.

- Berdasarkan jumlah penduduk Kota Buntok termasuk dalam kategori Kota Kecil dengan kebutuhan air bersih sebesar 130 1/orang/hari (Kementerian Pekerjaan Umum 2016).

- Kebutuhan non domestik sebesar 15\% dari kebutuhan domestik (Triatmadja 2016).

- Kehilangan air sebesar 20\% (Triatmadja 2016).

- Fluktuasi kebutuhan air bersih (Tabel 1).

4. Analisis kebutuhan dan ketersediaan air bersih yaitu dengan membagi kebutuhan air di tiap junction, dengan menyesuaikan data Sambungan Rumah di PDAM Kota Buntok pada tiap jaringan di daerah layanan. Hasil prediksi kebutuhan debit air tahun 2038 yang akan disimulasi menggunakan perangkat Bentley WaterCADv8i menjadi dasar rencana pengembangan jaringan distribusi

5. Analisa kelayakan ekonomi:

- Benefit Cost Ratio (BCR)

Perhitungan BCR menggunakan Rumus: (Giatman 2007):

dengan:

$$
B C R=\frac{P V \text { Manfaat }}{P V \text { Biaya }}
$$

$P V=$ Present Value

$B C R=$ Benefit Cost Ratio

- $\quad$ Net Benefit $(B-C)$ yaitu selisih antara jumlah benefit dengan jumlah cost.

- Internal Rate of Return (IRR)

Nilai IRR dihitung dengan rumus (Kodoatie 2005):

dengan:

$$
I R R=I^{\prime}+\frac{(B-C)^{\prime}}{(B-C)^{\prime}-(B-C)^{\prime \prime}}\left(I^{\prime \prime}-I^{\prime}\right)
$$

$I^{\prime} \quad=$ suku bunga dengan nilai $(B-C)$ positif

$I^{\prime \prime} \quad=$ suku bunga dengan nilai $(B-C)$ negatif

$(\mathrm{B}-\mathrm{C})^{\prime}=$ Net benefit $(B-C)$ positif

$(\mathrm{B}-\mathrm{C}) "=\quad$ Net benefit $(B-C)$ negative

- Rumus perhitungan titik impas investasi (Giatman 2007):

$$
k=\frac{\text { investasi }}{\text { annual benefit }} x \text { periode waktu }
$$

Dengan :

$$
\begin{array}{ll}
k & =\text { periode pengembalian } \\
\text { Investasi } & =\text { modal yang digunakam } \\
\text { Annual benefit } & =\text { keuntungan tiap tahun }
\end{array}
$$


Periode waktu $=$ tahun

- Analisa sensitivitas dengan keadaan terjadinya 10\% penurunan manfaat, $10 \%$ kenaikan biaya, dan penundaan penyelesaian proyek

6. Penetapan harga air per $\mathrm{m}^{3}$ PDAM Kota Buntok

\section{Hasil dan Pembahasan}

\subsection{Prediksi Jumlah Penduduk, Analisa Kebutuhan dan Ketersediaan Air Bersih}

Jumlah penduduk pada tahun akhir tahun 2018 adalah 37,117 jiwa. Hasil prediksi jumlah penduduk pada daerah layanan sampai tahun 2038 adalah 48,896 jiwa dan hasilnya digunakan sebagai kebutuhan rencana pengembangan untuk kebutuhan masing-masing wilayah serta kebutuhan air-rata-rata disajikan pada Tabel 3.

Dilihat Tabel 3 kebutuhan air bersih diperoleh jumlah kebutuhan rata-rata pada daerah eksisting sebesar $55.95 \mathrm{lt} / \mathrm{dt}$, kebutuhan harian maksimum sebesar $64.34 \mathrm{lt} / \mathrm{dt}$ dan kebutuhan air pada jam puncak $87.28 \mathrm{lt} / \mathrm{dt}$ sedangkan debit produksi sebesar $85 \mathrm{lt} / \mathrm{dt}$, sehingga debit tidak terpenuhi pada saat jam puncak sehingga diperlukan tambahan kapasitas produksi.

Ketersediaan debit sumber air baku adalah sebesar 1,000 lt/dt. Adapun debit kebutuhan rata-rata penduduk sebesar $55.95 \mathrm{lt} / \mathrm{dt}$ dengan kehilangan air $20 \%$ maka masih bisa $100 \%$ mampu terlayani. Pada tahun 2038 kebutuhan rata-rata sebesar $101.53 \mathrm{lt} / \mathrm{dt}$ dengan debit air yang tersedia cukup mampu untuk memenuhi kebutuhan air bersih penduduk Kota Buntok dan masih terdapat sisa debit. Kapasitas Instalasi Pengolahan Air Bersih PDAM Kota Buntok sebesar 85 lt/dt tidak mampu memenuhi kebutuhan air rata-rata, maksimum dan kebutuhan puncak, sehingga untuk mengoptimalkan pelayanan diperlukan tambahan instalasi sebanyak 2 unit dengan kapasitas masing-masing sebesar 30 lt/dt dan 20 lt/dt.

Tabel 3. Kebutuhan Air Rata-rata, Kebutuhan Harian Mininum dan Kebutuhan Jam Puncak sampai dengan tahun 2038

\begin{tabular}{|c|c|c|c|c|c|c|c|c|}
\hline \multirow{2}{*}{ No } & \multirow{2}{*}{ Tahun } & \multirow{2}{*}{$\begin{array}{c}\text { Q } \\
\text { Produksi }\end{array}$} & $\begin{array}{c}\text { Kapasitas } \\
\text { Reservoir }\end{array}$ & $\begin{array}{c}\text { Rata- } \\
\text { rata }\end{array}$ & $\begin{array}{c}\text { Harian } \\
\text { Minimum }\end{array}$ & $\begin{array}{c}\text { Jam } \\
\text { Puncak }\end{array}$ & $\begin{array}{c}\text { Kesentase } \\
\text { Kersih }\end{array}$ & \multirow{2}{*}{ Ket } \\
\cline { 5 - 6 } & $(\mathrm{lt} / \mathrm{dt})$ & $(\mathrm{lt} / \mathrm{dt})$ & $(\mathrm{lt} / \mathrm{dt})$ & $(\mathrm{lt} / \mathrm{dt})$ & $(\mathrm{lt} / \mathrm{dt})$ & $\%$ & \\
\hline 1 & 2018 & 85 & 1,000 & 55.95 & 64.34 & 87.28 & 76.18 & $\begin{array}{c}\text { Defisit pada Jam } \\
\text { Puncak }\end{array}$ \\
\hline 2 & 2023 & 85 & 1,000 & 74.09 & 85.21 & 115.59 & 100 & $\begin{array}{c}\text { Defisit pada Harian } \\
\text { Maksimum dan Jam } \\
\text { Puncak }\end{array}$ \\
\hline 3 & 2028 & 85 & 1,000 & 79.17 & 91.04 & 123.50 & 100 & Tidak memenuhi \\
\hline 4 & 2033 & 85 & 1,000 & 95.00 & 109.25 & 148.21 & 100 & Tidak memenuhi \\
\hline 5 & 2038 & 85 & 1,000 & 101.53 & 116.76 & 158.38 & 100 & Tidak memenuhi \\
\hline
\end{tabular}

\subsection{Evaluasi Kondisi Eksisting dan Simulasi Program WaterCAD V8i}

Gambar 2 menampilkan model jaringan eksisting PDAM Kota Buntok dengan pipa transmisi terbuat dari bahan pipa galvanis iron dan pipa distribusi jenis PVC dengan sumber air permukaan untuk melayani kebutuhan air bersih dengan potensi debit Sungai Barito adalah 1,000 lt/dt. Kapasitas IPA produksi air bersih terpasang dari sebesar 85 lt/dt PDAM Buntok melayani tiga kelurahan dan satu desa yaitu Kelurahan Buntok Kota sebesar $66.13 \%$, Kelurahan Hilir Sper sebesar 79.06\%, Kelurahan Jelapat sebesar 67.96\% dan Desa Pamait sebesar 31.55\% dengan panjang jaringan distribusi sepanjang $55.58 \mathrm{~km}$ dan dapat melayani 6,128 SR. 


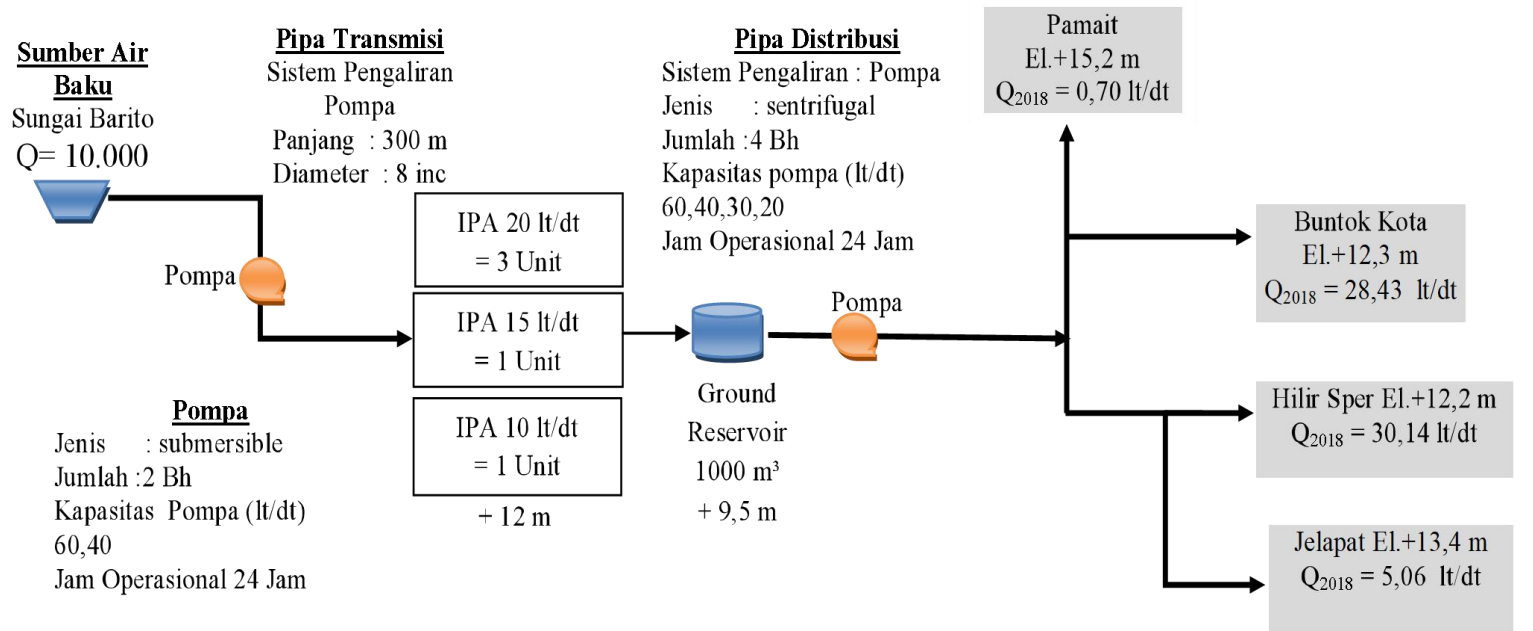

Gambar 2. Skema Sistem Jaringan Distribusi

Sumber air terletak pada elevasi $+6 \mathrm{~m}$. Pengaliran air distibusi dari reservoir ke daerah layanan (junction) dilakukan menggunakan pompa karena jenis topografi Kota Buntok yang relatif datar. Untuk melayani kebutuhan air PDAM Kota Buntok menggunakan 2 buah pompa yang terletak pada sumber dengan kapasitas masing-masing sebesar 60 lt/dt dan 40 lt/dt, sedangkan 4 buah pompa distribusi dipasang paralel setelah ground reservoir dengan kapasitas masing-masing sebesar 100 lt/dt, 60 lt/dt, 40 lt/dt dan 20 lt/dt. Dengan jam kerja pompa selama 24 jam. Asumsi kebutuhan air adalah 130 1/org/hari.

Gambar 3 menjelaskan kecepatan pada jaringan pipa terdapat beberapa titik dengan kecepatan kurang dari $0.3 \mathrm{~m} / \mathrm{dt}$ dan tidak sesuai dengan standar kriteria perencanaan teknis penyelenggaraan air minum yang berkisar $0.3-4.5 \mathrm{~m} / \mathrm{dt}$. Untuk itu diperlukan perbaikan diameter pipa dibeberapa lokasi agar kecepatannya dapat sesuai dengan standar kriteria.

Gambar 4 menunjukkan analisa headloss gradient secara umum pada kondisi eksisting pada jam puncak memenuhi kriteria perencanaan teknis dengan batas $0-15 \mathrm{~m} / \mathrm{km}$. Pada Gambar 5 menunjukkan hasil simulasi tekanan kondisi eksisting pada jam minimum berkisar antara 4.08-5.20 atm dan pada jam puncak berkisar antara 3.98-5 atm. Hasil tersebut sesuai dengan kriteria perencanaan $(0.5-8 \mathrm{~atm})$.

\subsection{Rencana Kondisi Pengembangan}

Pengembangan dilakukan hingga 20 tahun kedepan yaitu sampai dengan tahun 2038. Kapasitas produksi air bersih eksisting sebesar 85 lt/dt tidak dapat memenuhi kebutuhan air bersih pada setiap jenis kebutuhan air bersih maka diperlukan tambahan instalasi pengolahan air bersih sebanyak 2 unit dengan masing-masing berkapasitas sebesar $30 \mathrm{lt} / \mathrm{dt}$ dan $20 \mathrm{lt} / \mathrm{dt}$. Kapasitas reservoir sebesar 1,000 1/dt sampai dengan tahun 2038 masih mampu memenuhi kebutuhan volume penampungan jadi tidak diperlukan tambahan kapasitas. Untuk mengetahui jumlah air hasil produksi yang didistribusikan kepada pelanggan secara akurat, sebaiknya PDAM Tirta Barito perlu memasang meter air induk untuk mengukur produksi air telah didistribusikan serta untuk mengetahui tren atau fluktuasi pemakaian harian selama 24 jam pada PDAM Kota Buntok.

Untuk Gambar 6 simulasi aliran pipa secara umum pada kondisi pengembangan pada jam minimum diketahui kecepatan pada kecepatan jaringan pipa kecepatan berkisar antara 0.02-0.4 $\mathrm{m} / \mathrm{dt}$ dan terdapat titik yang tidak memenuhi memenuhi kriteria perencanaan yaitu antara $0.3-4.5$ $\mathrm{m} / \mathrm{dt}$ dikarenakan debit yang mengalir sangat kecil dan kecepatan berkisar antara 0.3-2.3 m/dt telah memenuhi kriteria perencanaan yaitu antara $0.3-4.5 \mathrm{~m} / \mathrm{dt}$.

Pada Gambar 7 disajikan hasil simulasi aliran pipa secara umum pada kondisi pengembangan pada jam minimum dapat diketahui headloss gradient telah sesuai dengan syarat perencanaan yaitu $0-15 \mathrm{~m} / \mathrm{km}$.

Gambar 8 menunjukkan aliran pipa secara umum pada kondisi pengembangan pada jam ke puncak dapat diketahui headloss gradient telah sesuai dengan syarat perencanaan yaitu $0-15 \mathrm{~m} / \mathrm{km}$. 
Pada Gambar 9 dan Gambar 10 menunjukkan tekanan pada jam minimum dan maksimum yang telah memenuhi kriteria perencanaan teknis air minum yaitu antara 0.5-8 atm.

Klorin cairan $(\mathrm{NaOCl})$ atau Sodium Hypochlorite digunakan dalam proses desinfeksi untuk simulasi kualitasnya. Dengan metode penginjeksian klorin pada inlet reservoir dengan dosis 0.4 $\mathrm{mg} / \mathrm{L}$ secara konstan hingga mencapai batas sisa klorin yang diharapkan.

Hasil simulasi injeksi ini menunjukan sisa klorin jam puncak berkisar 0.387- $0.399 \mathrm{mg} / \mathrm{L}$, dan jam rendah berkisar 0.383-0395 mg/L. Nilai tersebut masuk syarat kriteria $0.3 \mathrm{mg} / \mathrm{L} \leq$ sisa klorin $\leq$ $0.5 \mathrm{mg} / \mathrm{L}$. Pada pengoperasian jaringan pipa hari pertama, air baru dapat digunakan setelah pukul 06.00, karena baru setelah pukul 07.00 tersebut semua junction memenuhi syarat kriteria sisa klorin dan hasil simulasi pada hari berikutnya telah mengalami sisa klorin yang sesuai dengan batas sisa klorin.

Pada Gambar 11 menunjukan bahwa hasil simulasi sisa klorin dengan program WaterCAD V8i pada jam puncak dihari pertama, untuk pipa pada jaringan pipa distribusi ke arah kanan tandon yaitu J-2 sampai J-30. Konsentrasi sisa klorin akan semakin berkurang dengan semakin bertambahnya jarak dari tandon ke junction. Pada J-2 konsentrasi sisa klorin $0.3994 \mathrm{mg} / \mathrm{L}$, pada J22 turun menjadi $0.3990 \mathrm{mg} / \mathrm{L}$, sedangkan pada titik terjauh J-30, konsentrasi sisa klorin semakin menurun menjadi $0.3982 \mathrm{mg} / \mathrm{L}$.

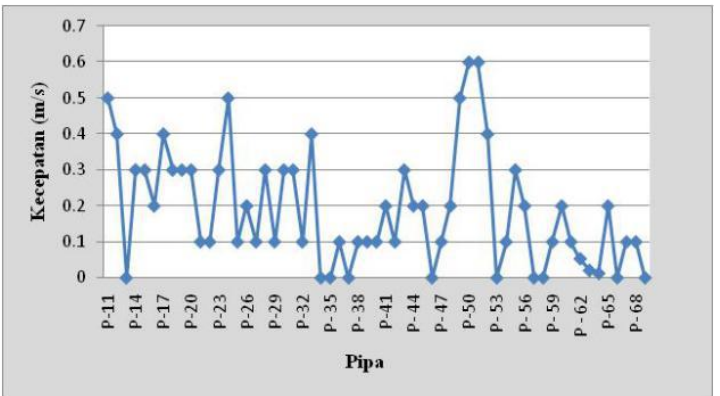

Gambar 3. Grafik Kecepatan Kondisi Eksisting pada jam puncak

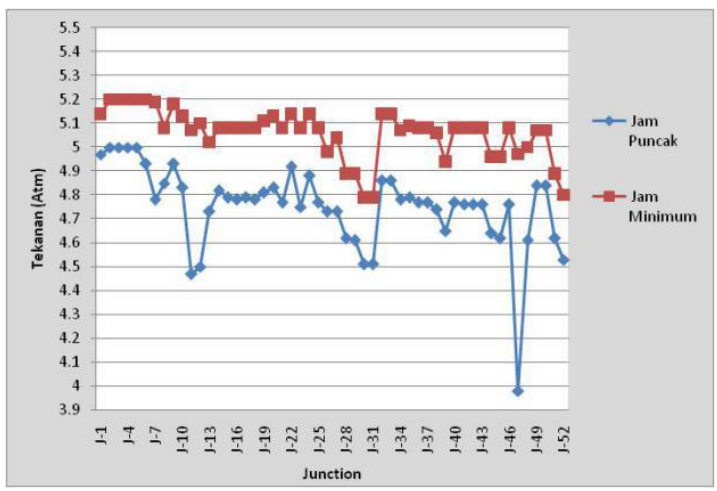

Gambar 5. Grafik Tekanan Kondisi Eksisting

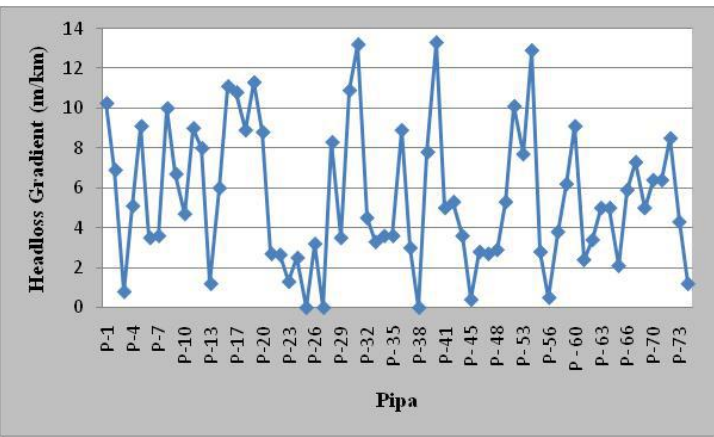

Gambar 7. Grafik Headloss Gradient Kondisi Pengembangan Jam puncak

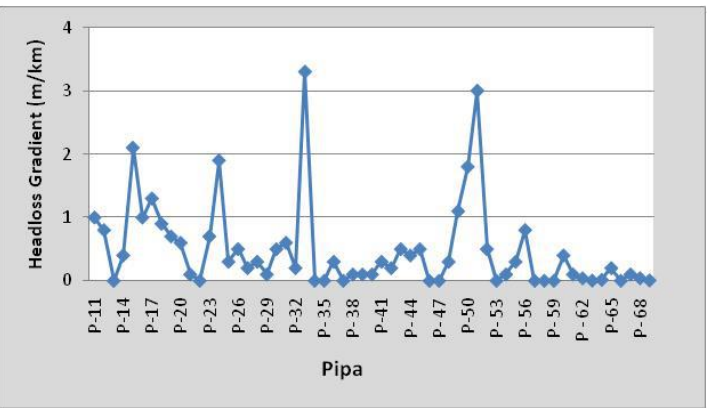

Gambar 4. Grafik Headloss Gradient Kondisi Existing pada jam puncak

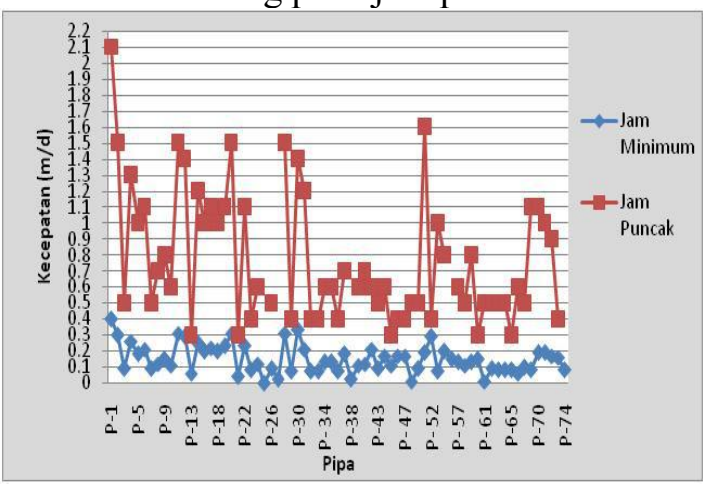

Gambar 6. Grafik Kecepatan Kondisi Pengembangan pada Jam Puncak

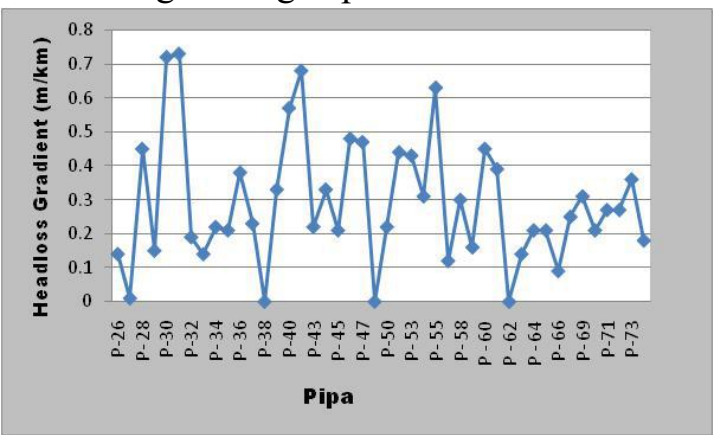

Gambar 8. Headloss Gradient Kondisi Pengembangan ada jam minimum 


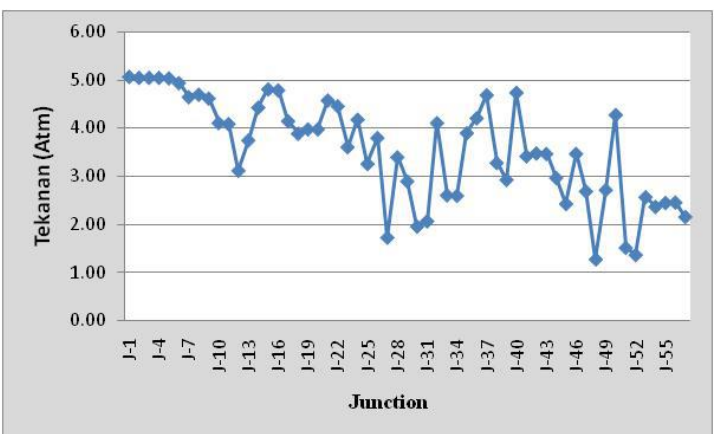

Gambar 9. Grafik Tekanan Titik Simpul Kondisi Pengembangan pada Jam Puncak

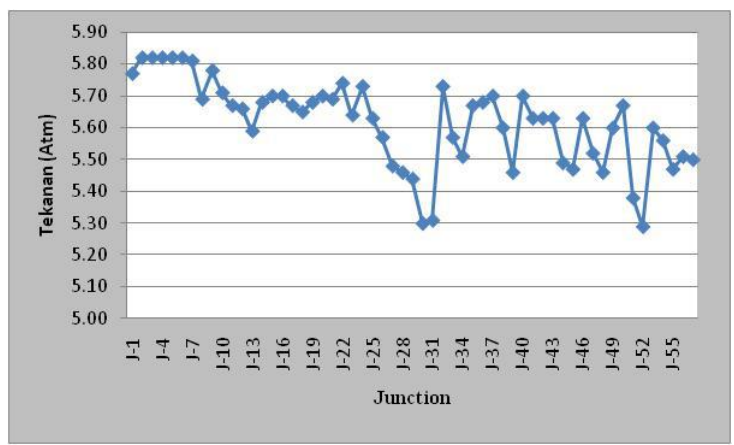

Gambar 10. Grafik Tekanan Titik Simpul Kondisi Pengembangan pada Jam Minimum

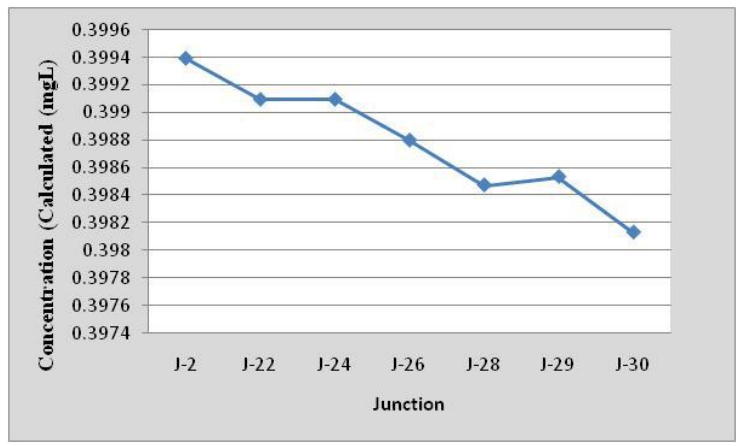

Gambar 11. Konsentrasi Sisa Klorin pada Junction untuk hari Pertama

Tabel 4. Harga Air Saat $B=C$ berbagai suku bunga tahun 2019

\begin{tabular}{|c|c|r|l|}
\hline $\begin{array}{c}\text { Suku } \\
\text { Bunga } \\
(\%)\end{array}$ & $\begin{array}{c}\text { Manfaat } \\
\text { Produksi Air } \\
\left(\mathrm{m}^{3} / \mathrm{th}\right)\end{array}$ & $\begin{array}{c}\text { Biaya } \\
(\text { Annual Cost })\end{array}$ & $\begin{array}{c}\text { Harga } \\
\text { Air } \\
\left(\mathrm{Rp} / \mathrm{m}^{3}\right)\end{array}$ \\
\hline 6 & $1,947,215$ & $9,642,390,161$ & 4,952 \\
\hline 7 & $1,947,215$ & $9,933,248,852$ & 5,101 \\
\hline 8 & $1,947,215$ & $8,263,281,593$ & 4,244 \\
\hline 9 & $1,947,215$ & $10,546,989,354$ & 5,416 \\
\hline 10 & $1,947,215$ & $10,869,339,939$ & 5,582 \\
\hline 12.5 & $1,947,215$ & $11,718,037,929$ & 6,018 \\
\hline 13 & $1,947,215$ & $11,894,707,027$ & 6,109 \\
\hline 14 & $1,947,215$ & $12,255,237,027$ & 6,294 \\
\hline 15 & $1,947,215$ & $12,624,163,738$ & 6,483 \\
\hline
\end{tabular}

\subsection{Analis Ekonomi}

Biaya proyek yang dibutuhkan untuk rencana pengembangan sistem jaringan distribusi air bersih PDAM Kota Buntok sebagai berikut:

- Biaya modal yang diperlukan sebesar Rp. 13,905,747,800. Yang terdiri dari biaya langsung sebesar Rp.12,360,664,700 berupa biaya konstruksi tambahan pada unit instalasi pengolahan dan unit distribusi serta biaya tidak sebesar Rp.1,545,083,100.

- Biaya modal tersebut akan ditambahkan dengan biaya konstruksi terhadap konstruksi yang sudah terbangun untuk selanjutnya dikonversikan kenilai tahunan (annual value) menjadi sebesar Rp.2,395,089,196.

- Biaya tahunan merupakan biaya operasional dan pemeliharaan (OP) yang digunakan PDAM Kota Buntok untuk pengolahan dan biaya administrasi dan gaji pegawai adalah sebesar Rp. $6,837,076,381$.

Suku bunga yang digunakan untuk analisis ekonomi proyek pengembangan sistem penyediaan air bersih di PDAM Kota Buntok berdasarkan suku bunga bank Indonesia sebesar 6\%, yang ditinjau nilai BCR, B-C, IRR, titik impas investasi serta analisa sensitivitas. 
Pada Tabel 4 menampilkan harga air minimal ketika $B=C$ dengan berbagai suku bunga. Analisis ekonomi dan analisa sensitivitas pada saat $B=C$. Penetapan harga air pada kajian ini berdasarkan kondisi paling kritis yaitu pada saat biaya naik $10 \%$ sedangkan manfaat turun $10 \%$ sehingga didapatkan tarif harga air minimal sebesar Rp. 6,100.

Hasil analisa ekonomi didapatkan nilai BCR adalah 1.23 dan dikatakan layak karena BCR $>1$. B$\mathrm{C}$ bernilai positif Rp. 52,124,345 dan dianggap layak. Proyek ini dianggap menguntungkan karena memiliki nilai IRR $12.14 \%$ dan nilainya lebih besar dari suku bunga BI 6\%. Titik impas investasi terjadi pada tahun ke 11 (tahun 2030). Hasil analisa sensitivitas dari berbagai suku bunga $6 \%-14 \%$ menghasilkan BCR lebih dari satu sehingga proyek pengembangan sistem jaringan air bersih dapat dikatakan layak dibangun.

\subsection{Penetapan Harga Air Berdasarkan Willingness To Pay}

Berdasarkan analisa perhitungan WTP rata-rata masyarakat di wilayah layanan PDAM Kota Buntok, kemampuan warga membayar adalah sebesar Rp. 4,200. Maka dari itu pemerintah dapat memberikan subsidi agar masyarakat bisa membeli air. Nilai subsidi yang merupakan biaya yang digunakan untuk keperluan konstruksi PDAM Kota Buntok sebesar Rp. 13,905,747,800.

\section{Kesimpulan}

Untuk mewujudkan sistem pengembangan jaringan yang mampu melayani hingga tahun 2038 dilakukan analisa kondisi eksisting dan rencana pengembangan. Dengan ketersediaan debit sumber air baku sebesar 1,000 lt/dt, debit kebutuhan rata-rata penduduk $101.53 \mathrm{lt} / \mathrm{dt}$ dengan kehilangan air $20 \%$ maka masih cukup untuk melayani kebutuhan air bersih penduduk Kota Buntok hinga tahun 2038. Hasil analisa hidrolis kondisi eksisting menunjukan tekanan dan headloss gradient memenuhi kriteria teknis sedangkan kecepatannya tidak sesuai standar perencanaan sehingga distribusi air bersih pada lokasi studi menjadi terganggu dan oleh karena itu perlu dilakukan perbaikan diameter pipa.

Rencana pengembangan jaringan perpipaan air bersih di PDAM Kota Buntok berdasarkan prediksi peningkatan penduduk daerah layanan maka diperlukan tambahan instalasi pengolahan air bersih sebesar $30 \mathrm{lt} / \mathrm{dt}$ dan $20 \mathrm{lt} / \mathrm{dt}$ yang dapat dilakukan secara bertahap. Berdasarkan simulasi WaterCad V8i disimpulkan jaringan pipa memiliki kondisi hidraulis yang memenuhi batas kriteria teknis, walaupun kecepatan aliran ketika jam minimum menjadi terlalu lambat.

Hasil uji kualitas air hasil produksi instalasi PDAM Kota Buntok telah sesuai syarat kriteria. Proses desinfeksi menggunakan klorin cair atau Sodium Hypochlorite $(\mathrm{NaOCl})$ dibutuhkan agar kualitas air tetap terjaga. Pembubuhan injeksi di inlet tandon sebesar $0.4 \mathrm{mg} / \mathrm{l}$ secara konstan.

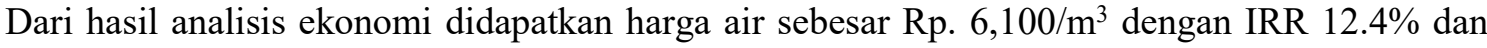
BEP selama 11 tahun. Analisis kemampuan membayar masyarakat sebesar Rp. 4,200 maka dari itu diperlukan subsidi pemerintah agar air bersih dapat dibeli oleh masyarakat. sebesar Rp.13,905,747,800.

\section{Daftar Pustaka}

Azhoni, Adani, Simon Jude, and Ian Holman. 2018. "Adapting to Climate Change by Water Management Organisations: Enablers and Barriers." Journal of Hydrology.

Direktorat Jenderal Cipta Karya. 2007. Kriteria Perencanaan Sistem Penyediaan Air Bersih. Kementerian PU.

Giatman. 2007. Ekonomi Teknik. Jakarta: Raja Grafindo Persada.

Izinyon, O C, and B U Anyata. 2009. "Water Distribution Network Modelling of a Small Community Using Watercad Simulator." Global Journal of Engineering Research 10(1): 3547.

Kementerian Pekerjaan Umum. 2016. Peraturan Menteri Pekerjaan Umum No 27/PRT/M/2016 Tentang "Penyelenggaraan Sistem Penyediaan Air Minum. Jakarta: Kementerian PU.

Kodoatie, Robert J. 2005. Analisis Ekonomi Teknik. Yogyakarta: Andi Yogyakarta. 
Lufira, Rahmah Dara, and Suwanto Marsudi. 2012. "Optimasi Dan Simulasi Sistem Penyediaan Jaringan Air Bersih Di Kecamatan Kademangan Kabupaten Blitar.” 3: 6-14.

M. Walski, Thomas et al. 2003. "Advanced Water Distribution Modeling and Management." Methods.

Siska, Eva Mia, and Kaoru Takara. 2015. "Achieving Water Security in Global Change: Dealing with Associated Risk in Water Investment.” Procedia Environmental Sciences 28(SustaiN 2014): 743-49.

Sonaje, Nitin P., and Mandar G. Joshi. 2015. "A Review of Modeling an Application of Water Distribution Networks (WDN) Softwares." International Journal of Technical Research and Applications.

Susilo, Gatot, and Muhammad Jafri. 2019. "The Analysis of Rainwater Harvesting Carrying Capacity on Water Domestic Supply for Dwelling Areas in Indonesia." Civil and Environmental Science.

Triatmadja, R. 2016. Teknik Penyediaan Air Minum Perpipaan. Pertama. Yogyakarta: Gadjah Mada University Press. 